Original Article

\title{
Comparative study on the antimicrobial activity of partitioned fractions of the stem-bark of ceiba pentandra (bombacaceae)
}

\author{
Njinga N. S. ${ }^{1}$, Sule M. I. ${ }^{2}$, Pateh U. U. ${ }^{3}$, Hassan, H. S. , Ache R. N. ${ }^{5}$, Abdullahi S. T. ${ }^{6}$ \& Danja B. A. \\ ${ }^{1,6}$ Lecturer, ${ }^{2}$ Professor, Department of Pharmaceutical \& M edicinal Chemistry, University of Ilorin, \\ ${ }^{3}$ Associate Professor \& Dean, Faculty of Pharmaceutical Sciences, ${ }^{4}$ Senior Lecturer, Department of Pharmaceutical \& \\ M edicinal Chemistry, Ahmadu Bello University, Zaria, ${ }^{5}$ Research Scholar, Department of Chemistry, Faculty of Sciences, \\ University of Yaounde I. Cameroon, 'Lecturer, Department of Chemical Sciences, Faculty of Science, \\ Federal University Kashere, Gombe, Nigeria.

\section{Correspondence} \\ Njinga N.S. \\ Lecturer, Department of Pharmaceutical \& M edicinal Chemistry, Faculty of Pharmaceutical Sciences, University of Ilorin. \\ E-mail : ngastanjin@yahoo.com
}

\begin{abstract}
Due to the emergence of more and more drug resistance bacteria and the reported antibacterial activity of Ceiba pentandra, the antimicrobial activity of the partitioned ethyl-acetate and n-butanol fractions of the stem-bark of this plant were carried out on the following clinical isolates: Staphylococcus aureus; Streptococcus pyrogenes; corynebacterium ulcereans; Escherichia coli; Salmonella typhi; Shigella dysenterea; Enterococcus aerogenes; Pseudomonas aeruginosa; klebsiella pneumonia and the fungi Trichophytom rubrum, Microsporum sp., Aspergillus fumigatus and Aspergillus niger . Agar diffusion and broth delusion methods were used in this study. The ethyl acetate fraction showed wide spectrum antibacteria activity (with zones of inhibition between $27 \mathrm{~mm}$ and $37 \mathrm{~mm}$ ) while the $n$-butanol extract showed activity only against the gram negative bacteria (zones of inhibition between $20 \mathrm{~mm}$ and $21 \mathrm{~mm}$ ). The M IC ranged from 0.65 to $2.5 \mathrm{mg} / \mathrm{ml}$ and 2.5 to $5 \mathrm{mg} / \mathrm{ml}$ and $\mathrm{M} \mathrm{BC}$ ranged from $2.5 \mathrm{mg} / \mathrm{ml}$ and $5-10 \mathrm{mg} / \mathrm{ml}$ for the ethylacetate and $\mathrm{n}$-butanol respectively. Both fractions showed no activity against the fungi used in this study. The preliminary phytochemistry of the ethyl acetate showed the presence of only flavonoid and this may explain the activity against all the bacteria. The n-butanol showed the presence of carbohydrates, saponins, tannins and cardiac glycoside and the absence of flavonoid and alkaloids. This study justifies the use of this plant in herbal medicine.
\end{abstract}

Keywords: antimicrobial, Ceiba pentandra, minimum inhibitory concentration, bacteria

\section{Introduction}

Emergence of multidrug resistant pathogens has been reported to be one of the leading causes of death worldwide ${ }^{[1]}$ with infectious diseases responsible for $68 \%$ of all deaths globally in $2012^{[2]}$. Many infectious microorganisms' are resistant to synthetic drugs and it has become the major concern for health institutions, pharmaceutical companies and governments all over the world; thus there is need for an alternative therapy ${ }^{[3]}$. Medicinal plants

\begin{tabular}{|c|}
\hline Access this article online \\
\hline Quick Response Code \\
\hline
\end{tabular}
contain numerous active constituents of great therapeutic value and have been used as an exemplary source for centuries as an alternative remedy for treating human disease ${ }^{[4]}$.
Approximately $80 \%$ of the third world population depend on traditional medicines for maintaining general health and combating many diseases ${ }^{[5]}$.

One of such plant widely used in traditional medicine in Nigeria is Ceiba pentandra. The bark decoction has been used as a diuretic, aphrodisiac, and to treat headache, as well as type II diabetes ${ }^{[6]}$. The stem bark of Ceiba pentandra, is used locally in the treatment of wounds, cough, high blood pressures, diarrhoea, dysentery, yellow fever and tumours, diabetes mellitus and malaria ${ }^{[7,8,]}$. This plant is a tree that grows as much as $65 \mathrm{~m}$ high and can be $10 \mathrm{~m}$ or more in girth, with long cylindrical bole and huge wide-spreading buttresses that can be up to $8 \mathrm{~m}$ high. They belong to secondary forests, and are seldom (if ever) found in virgin forests, but conspicuous in savanna ${ }^{[6]}$.

C. pentandra have been reported to contain bioactive 
substances such as glycosides, tannins, tannins, saponins, sesquiterpene lactones, flavonoids, polyuronoids, reducing sugars, phlobatannins etc ${ }^{[7,9]}$. Some compounds isolated from the bark of this plant include vavain 3'-O-B-Dglucoside, and its aglycone, vavain; flavan-3-ol, (+)catechin ${ }^{[10]}$, pentandrin and pentandrin glucoside and betasistosterol and 3-beta-D-glucopyranoside ${ }^{[11]}$.

This plant has been shown to possess antimicrobial activity

${ }^{[2]}$ but there is no information on the phytochemistry, M IC and $M B C$ of the partitioned ethyl acetate and n-butanol fractions of the methanolic extract of the stem bark of this plant.

\section{Materials and Methods \\ Plant collection and identification}

The plant sample was collected in Zaria City, Kaduna State, Nigeria, in October, 2008. The plant was authenticated in the Herbarium of the Department of Biological Sciences, Ahmadu Bello University, Zaria, Nigeria, where a voucher specimen (7059) was deposited.

\section{Preparation and Extraction of Plant material}

The stem-barks were removed and air-dried for several weeks and size reduced using mortar and pestle. Four hundred grams $(800 \mathrm{~g})$ was defatted exhaustively with petroleum ether $\left(60-80^{\circ} \mathrm{C}\right)$ in a soxhlet extractor. The marc was then extracted with methanol using maceration method. The extract was concentrated in vacuo to solid residue. The methanol extract $(15 \mathrm{~g})$ was then partitioned (wet portioning) using ethyl acetate and n-butanol. The fractions were concentrated under reduced pressure to solid residue ${ }^{[13]}$.

\section{Test organisms}

The clinical isolates viz; Staphylococcus aureus; Streptococcus pyrogenes; Corynebacterium ulcereans; Escherichia coli; Salmonella typhi; Shigella dysenterea; Enterococcus aerogenes; Pseudomonas aeruginosa; klebsiella pneumonia and the fungi Trichophytom rubrum, Microsporum sp., Aspergillus fumigatus and Aspergillus niger were gotten from the Ahmadu Bello University Teaching Hospital, Zaria. All the micro-organisms were checked for purity and maintained in slants of agar.

\section{Phytochemical screening}

Phytochemical screening was carried out on the methanolic, ethylacetate, and n-butanol extract of the stem bark of Ceiba pentandra using standard procedures of analysis ${ }^{[13,14]}$.

\section{Cultivation and standardization of test organism}

A loop full of each of the test organisms was taken from the agar slant and sub cultured into test tubes containing $20 \mathrm{ml}$ of sterile nutrient agar (for bacteria) and sabouraud dextrose agar medium (for the fungi). The test tubes were then incubated for 24 hours at $37^{\circ} \mathrm{C}$ for bacteria and $27^{\circ} \mathrm{C}$ for 48hours for the fungi. The growth culture was standardized using sterile normal saline to obtain a density of $10^{6} \mathrm{cfu} / \mathrm{ml}$ for bacteria. A sporulated test fungal spores was harvested with $0.05 \%$ Tween 80 in sterile normal saline and standardized to $10^{6}$ spores $/ \mathrm{ml}$.

\section{Preparation of culture media}

The prescribed quantities of the dehydrated bacteriological culture media was weighed and hydrated with distilled water according to the manufacturers specification. Where necessary, gentle heat was applied to aid dissolution and the resultant suspensions were dispensed into clean bottles and sterilized at $121^{\circ} \mathrm{C}$ for 15 minutes in an Adelphi bench autoclave.

\section{Assay of Antimicrobial activity}

The antibacterial screening was carried out using agar diffusion method ${ }^{[15]}$. The test organisms were first inoculated into tubes of nutrient broth (for the bacteria) and sabouraud dextrose agar (for the fungi) separately and incubated at $37^{\circ} \mathrm{C}$ for $18 \mathrm{~h}$. Each of the cultures were then adjusted to $0.5 \mathrm{McFarland}$ turbidity standard and $(0.2 \mathrm{ml})$ inoculated onto M ueller Hinton Agar ( $\mathrm{MHA}, \mathrm{Oxo}$ id) in petri plates (diameter $15 \mathrm{~cm}$ ). A sterile cork borer was then used to make wells ( $6 \mathrm{~mm}$ diameter) for the extracts on each of the plates containing cultures of the different test organisms. The extracts were separately re-dissolved in dimethyl suphoxide (DMSO) to obtain initial concentrations of $20 \mathrm{mg} / \mathrm{ml} .0 .5 \mathrm{ml}$ of each of the extract 
were then introduced into the wells using sterile Pasteur pipettes. $0.5 \mathrm{ml}$ of DM SO only was introduced in another well to serve as negative control. Wells containing the standard antimicrobials sparfloxin and fluconazole $(0.5 \mathrm{mg} / \mathrm{ml})$ were included as positive control. The culture plates were allowed to stand on the working bench for 30 min for pre diffusion and were then incubated at $37^{\circ} \mathrm{C}$ and $27^{\circ} \mathrm{C}$ for 24 hrs and 48 hours for the bacteria and fungi respectively. The Zones of inhibition were determined by measurement of diameter zones of inhibition $(\mathrm{mm})$ (against the test organisms) around each of the extracts and the antibiotics.

\section{M inimum Inhibitory Concentration (M IC)}

Broth dilution method was used to determine the M IC ${ }^{[16]}$. $10 \mathrm{ml}$ nutrient broth (prepared using manufacturers specifications) was dispensed into test tubes and sterilized at $121^{\circ} \mathrm{C}$ for 10 minutes and allowed to cool. M c-Farland's turbidity standard scale number 0.5 was prepared to give a turbid solution. Normal saline was inoculated with each of the test micro-organism and incubated at $37^{\circ} \mathrm{C}$ for 6 hrs to make a turbid suspension of the micro-organisms. After incubations, dilution of the micro-organism in normal saline was done until the turbidity $\left(1.5 \times 10^{6} \mathrm{cfu} / \mathrm{ml}\right)$ matched that of the Mc-Farland scale by visual comparism. A $5 \mathrm{ml}$ solution of the extract (ethyl acetate extract and $\mathrm{n}$ butanol of concentrations $10,5,2.5,1.25,0.625,0.312$ $\mathrm{mg} / \mathrm{ml}$ ) were mixed with $5 \mathrm{ml}$ of nutrient broth. From the suspension of the micro-organism in normal saline, $0.1 \mathrm{ml}$ was inoculated into the different concentrations of the extract in the nutrient broth. The broths were incubated at $37^{\circ} \mathrm{C}$ for $24 \mathrm{hrs}$ and The results after $24 \mathrm{hrs}$ were recorded.

\section{Determination of Minimum Bactericidal Concentration (MBC)}

Blood agar was prepared according to manufacturer's instruction, sterilized at $121{ }^{\circ} \mathrm{C}$ for 15 minutes. It was poured into sterile petri-dishes. The plates were allowed to cool and solidify. The contents of the MIC test tubes in the serial dilution were then sub-cultured on to the prepared plates and the plates were then incubated at $37{ }^{\circ} \mathrm{C}$ for 24 hours. After 24 hours and the results recorded ${ }^{[16]}$.

\section{Results}

Table 1 indicates that the plant does not contain much methanol soluble components. The methanol extract of this plant contain more water soluble content since most of the components remained in the aqueous portion followed by the $n$-butanol and ethyl acetate (Table 1). The ethyl acetate fraction was found to contain only flavonoids while the $n$-butanol fraction was found to contain carbohydrate, saponin, tannins and cardiac glycosides (Table 2).

The n-butanol fraction only showed activity against the gram negative bacteria (Salmonella typhi, Escherichia coli, Shigella dysenteriae and Klebsiella pneumonae) while the ethlyl acetate was active against both the gram negative and gram positive bacteria tested. Both fractions were inactive against Pseudomonas aerogenes and the fungi tested (Table 3). Both fractions showed lower zones of inhibition against the test organisms compared to that of the standard sparfloxin (table 3). The M IC was in the ranged $0.65-1.25 \mathrm{mg} / \mathrm{l}$ and $2.5-5 \mathrm{mg} / \mathrm{l}$ for the ethyl acetate and $\mathrm{n}$ butanol fraction respectively (Table 4). The MBC ranged between $2.5 \mathrm{mg} / \mathrm{ml}$ to $5 \mathrm{mg} / \mathrm{ml}$ and between $5 \mathrm{mg} / \mathrm{ml}$ to $10 \mathrm{mg} / \mathrm{ml}$ for the ethyl acetate fraction and the $\mathrm{n}$-butanol fraction respectively (Table 4).

Table 1 : Extractive values of methanolic extract of the stem-bark of Ceiba pentandra

\begin{tabular}{|l|c|c|c|}
\hline Extract & Colour & Weight (g) & Percentage yield (\%) \\
\hline Petroleum ether & Dark green & 3.00 & 0.375 \\
\hline M ethanol & Brown & 49.00 & 6.125 \\
\hline Ethyl acetate & Pale green & 2.40 & 16.000 \\
\hline n-butanol & Brown & 4.20 & 28.000 \\
\hline
\end{tabular}

Table 2 : Secondary metabolites present in the fraction

\begin{tabular}{|l|c|c|}
\hline \multirow{2}{*}{ Secondary metabolites } & \multicolumn{2}{|c|}{ Inference } \\
\cline { 2 - 3 } & EtOAc & $\mathrm{n}-\mathrm{BuOH}$ \\
\hline Carbohydrate & - & + \\
\hline Anthraquinones & - & - \\
\hline Saponin & - & - \\
\hline Steroid and Triterpenes & - & - \\
\hline & - & + \\
\hline Tannins & - & - \\
\hline Alkaloids & - & + \\
\hline Cardiac glycosides & - & - \\
\hline Flavonoid & + & - \\
\hline
\end{tabular}


Table 3 : shows the zone of inhibition of ethylacetate, n-butanol extract of Ceiba pentandra together with spafloxin and fluconzole on micro-organisms.

\begin{tabular}{|l|c|c|c|c|c|c|}
\hline M icro-organisms & Gram & \multicolumn{5}{|c|}{ Zone of Inhibition (mm) } \\
\hline & & Sterile water & Ethlyacetate fraction & n-butanol fraction & sparfloxin & Fluconazole \\
\hline Staphylococcus aureus & + & 0 & 32 & 0 & 44 & \\
\hline Streptococcus pyogenes & + & 0 & 27 & 0 & 50 & \\
\hline Corynebacterium ulcereans & + & 0 & 29 & 0 & 40 & \\
\hline Enterococcus aerogenes & + & 0 & 40 & 0 & 43 & \\
\hline Escherichia coli & - & 0 & 30 & 21 & 30 & \\
\hline Salmonella typhi & - & 0 & 37 & 20 & 52 & \\
\hline Shigella dysenteria & - & 0 & 34 & 20 & 50 & \\
\hline Pseudomonas aeruginosa & - & 0 & 0 & 0 & 35 & \\
\hline Klebsiella pneumonia & - & 0 & 37 & 20 & 28 & \\
\hline Trichophytum rubrum & & 0 & 0 & 0 & & 27 \\
\hline Candida albicans & & 0 & 0 & 0 & & 44 \\
\hline Microsporan spp & & 0 & 0 & 0 & & 30 \\
\hline
\end{tabular}

Table 4 : shows the minimum inhibitory concentration (MIC) and minimum bactericidal concentration (MBC) of ethylacetate and $n$ butanol extract of Ceiba pentandra on micro-organisms.

\begin{tabular}{|l|c|c|c|c|}
\hline M icro-organisms & \multicolumn{2}{|c|}{ Ethyl acetate } & \multicolumn{2}{c|}{ n-butanol } \\
\hline & \multicolumn{2}{|c|}{ (mg/ ml) } & \multicolumn{2}{c|}{ (mg/ ml) } \\
\hline & MIC & M BC & MIC & M BC \\
\hline Staphylococcus aureus & 1.25 & 2.5 & & \\
\hline Streptococcus pyogenes & 2.5 & 5.0 & & \\
\hline Corynebacterium ulcerans & 2.5 & 5.0 & & \\
\hline Enterococcus aerogenes & 0.62 & 5.0 & & \\
\hline Escherichia coli & 1.25 & 2.5 & 2.5 & 10.0 \\
\hline Salmonella typhi & 1.25 & 2.5 & 2.5 & 5.0 \\
\hline Shigella dysenteriae & 1.25 & 5.0 & 2.5 & 10.0 \\
\hline Klebsiella pneumoniae & 1.25 & 2.5 & 2.5 & 10.0 \\
\hline
\end{tabular}

\section{Discussion}

Results of phytochemical screening of the stem bark were consistent with previous investigations ${ }^{[7,17]}$ but the presence of flavonoid in this extract is not consistent with literature Kubmarawa et al. ${ }^{[12]}$. This may be due to the difference in environmental factors ${ }^{[18]}$. The antibacteria activity of the ethyl acetate fraction was more than that of the n-butanol fraction.

Averagely, it can be concluded that the gram negative bacteria were more susceptible to both fractions than the gram positive bacteria. This is in contrast to report that gram positive bacteria are more susceptible to plant extracts than gram negative bacteria ${ }^{[19]}$. Gilbert and Wight ${ }^{[20]}$ reported that gram negative micro-organisms are innately resistant to many antibacterial agents relative to gram positive bacteria due to the differences in their cell wall and membrane structure.
Kubmarawa et al. ${ }^{[12]}$ reported no activity of Ceiba pentandra on Staphylococcus aereus, Pseudomonas aeroginosa and Escherichia coli while this study showed activity against the afore mentioned bacteria. These differences can be due to the difference in climatic and soil conditions, age and period of plant collection ${ }^{[18]}$. The MIC values of both extract were all lower than the $\mathrm{MBC}$ for all the micro-organisms. This suggest that both fractions were bacteristatic at lower concentration and bactericidal at higher concentration.

Extracts of various medicinal plants containing phenolic and flavonoids have been previously reported to possess antimicrobial activity against human pathogenic microorganisms ${ }^{[21,22]}$ with some mechanisms of action such as inhibition of nucleic acid synthesis, cytoplasmic membrane function and energy metabolisms ${ }^{[23]}$. The antimicrobial activity of the ethyl acetate fraction might be due to one of the mechanisms of action mentioned above since it contains only flavonoids.

Reports also showed that the antibacterial activity can depend on the saponins and tannins content present in a plant extract ${ }^{[24,25]}$. Thus since the $\mathrm{n}$-butanol fraction contains both saponins and tannins, these could account for it antibacterial activity of the n-butanol while the flavonoids in the ethyl acetate fraction is responsible for the antibacterial activity.

It is therefore recommended that further work be done on 
isolating and testing the antibacterial activity of the flavonoids compounds responsible for the wide antibacterial activity of the ethyl acetate fraction.

\section{Conclusion}

Ceiba pentandra possesses antibacterial activity with the ethyl acetate fraction showing wide spectrum antibacterial activity than the n-butanol fraction which is active only against gram positive bacteria. Both fractions showed no antifungal activity. This study further justifies the use of this

\section{References}

1. Reddy P, Chadaga S, Noskin GA. Antibiotic considerations in the treatment of multidrug-resistant (MDR) pathogens: a case-based review.J Hosp M ed. 2009:4(6):E8-15.

2. WHO. The top 10 causes of death. Retrieved August, 2014 from

3. Al-Bari MAA, Sayeed MA, Rahman MS. Characterization and antimicrobial activities of extracts in a phenolic acid derivative produced by Streptomyces bangladeshiensis, a novel species collected in Bangladesh. Journal of Research in M edical Science; 2006;1: 77-81.

4. Nostro A, Germano MPD, Angelo V, Marino A., Cannatelli MA. Extraction methods and bioautography for evaluation of medicinal plant antimicrobial activity. Letters in Applied Microbiology 2000;30:379-84.

5. Debas HT, Laxminarayan R, Straus SE. Complementary and Alternative Medicine. In: Disease Control Priorities in Developing Countries. edited by Jamison DT, Breman JG, M easham AR, Alleyne G, Claeson M EvansDB et al. Washington. World Bank. 2006;69.

6. Burkill HM. The Useful plants of West Tropical Africa,1997;1:278-283.

7. Sule MI, Njinga NS, Musa AM., Magaji MG, Abdullahi A Phytochemical and antidiarrhoeal studies of the stem bark of Ceiba pentandra (bombacaceae). Nig. Journ. Pharm. Sci. 2009;8(1):143-148.

8. Asare P. Oseni LA. Comparative evaluation of Ceiba pentandra ethanolic leaf extract, stem bark extract and the combination thereof for in vitro bacterial growth inhibition. J. Nat.Sci. Res. 2013:2(5):44-49.

9. Adebayo-Tayo BC. Adegoke AA. Phytochemical and microbial screeing of herbal remedies in Akwa Ibom State, South Southern Nigeria. J. Med. Plants Res. 2008; 2(11), 306-310.

10. Ylva N, Hersham E, Premila P, Lars B. Two new isoflavones from Ceiba pentandra and their effects on cyclooxygenase-Catalyzed Prostaglandin Biosynthesis. J. Nat. Prod. 1998;61(1), 8-12.

11. Ngounou FN, Meli AL, Lontsi D, Sonndengam BL, Atta-Ur-Rahman, Choudhary MI, et al. New isoflavone from Ceiba pentandra. Phytochemistry, 2000; 54:107-110.

12. Kubmarawa D, Ajoku GA, Enwerem NM, Okorie DA. Preliminary phytochemical and antimicrobial screening of 50 medicinal plants from Nigeria. Afr. J. Biotechnol. 2007;6(14):1690-1696.

13. Brain KR, Turner TD. The practical Evaluation of Phytopharmaceutical. 1975; Wright Scientechnica, Bristol. plant in treating various ailments.

\section{Acknowledgements}

The authors acknowledge Mr Mikailu F. Abdullahi of Nigeian Institute of Leather and Science Technology, ZariaNigeria, the Ahmadu Bello University Teaching Hospital, Zaria - Nigeria and the staff of Department of Pharmaceutical and Medicinal Chemistry, University of Ilorin - Nigeria for their support and contribution to this work.

14. Trease GE, Evans WC. Pharmacognsy. 15th edn. 2002; Saunders Publishers, London.

15. Lino A, Deogracios O. The in-vitro antibacterial activity of Annona senegalensis, Securidacca longipendiculata and Steanotaenia araliacea-Ugandan M edicinl plants. Afri. Health Sci. 2006; 6(1): 31-35.

16. Usman $\mathrm{H}$, Abdulrahman $\mathrm{Fl}$, Ladan $\mathrm{AH}$. Phytochemical and Antimicrobial Evaluation of Tribulus terrestris L. (Zygophylaceae) Growing in Nigeria. Res. J. Bio. Sci. M edwell Journals, 2007 2(3): 244 247.

17. Akaneme F. Identification and preliminary phytochemical analysis of herbs that can arrest threatened miscarriage in Orba and Nsukka Touns of Enugu State. Afr. J. Biotechnol. 2008;7(1): 006-011.

18. Waterman PG, Mole S. Entrinsic factors influencing production of secondary metabolites in plants. In: Bernays EA (Ed) Insect - plant interactions, 1989; Volume 1, CRCPress, Boca Ranton, USA.

19. Rabe T, Staden J. Antibacterial activity of South African plants used for medicinal purposes. J. Ethanopharmacol. 1997;56: 81-87.

20. Gilbert P, Wright N. Non-plasmic resistance towards preservatives of pharmaceutical products. In: Board, R.G., Allwood, MC and Banks JG. (Ed) Preservatives in the Food, Pharmaceutical and Environmental Industries. Society for Applied Bacteriology. 1987; 255-279.

21. Ayaz F, Haylrlloglu-Ayaz S, Alpay-Karaoglu S, Gruz J, Valentová K, Ulrichová J, et al. Phenolic acid contents of kale (Brassica oleraceae L. var. acephala DC.) extracts and their antioxidant and antibacterial activities. Food Chem. 2008:107:19-25.

22. Rahman M, Moon S. Antimicrobial phenolic derivatives from Dendranthema zawadskii var. latilobum kitamura (Asteraceae). Arch. Pharm. Res. 2007;30: 1374-1379.

23. Cushnie TPT. Lamb AJ. Antimicrobial activity of flavonoids. Int. J. Antimicrob. Agents 2005;26:343-356

24. Avto P, Bucci R, Tava A, Vitali C, Rosato A, Bialy Z, et al. Antimicrobial activity of saponins from Medicago sp.: Structure -Activity Relationship. Phytotherapy Research. 2006;20: 454-457.

25. Njinga NS, Sule MI, Pateh UU, Hassan HS, Usman MA, Bilkisu A, et al. Phytochemical and Antimicrobial Activity of the Stem-Bark of Gardenia aqualla Stapf \& Hutch (Rubeacea). J. med. plants res, 2014;8(27):942-946. 